\title{
Oil spills and community health: Implications for resource limited settings
}

\author{
Albert SALAKO ${ }^{1}$, Oluwafolahan SHOLEYE ${ }^{2 \star}$ and Sunkanmi AYANKOYA ${ }^{1}$ \\ ${ }^{1}$ Obafemi Awolowo College of Health Sciences, Olabisi Onabanjo University, Sagamu, Nigeria. \\ ${ }^{2}$ Department of Community Medicine and Primary Care, Olabisi Onabanjo University Teaching Hospital, \\ Sagamu, Nigeria.
}

Accepted June 18, 2012

\begin{abstract}
Oil spillage has become of increased relevance in recent times because of the magnitude with which it occurs, the effects it has on the environment, and the quality of life of people residing in the affected areas. The World Health Organization (WHO) has drawn the attention of many member states to the burden of non-communicable diseases on the limited resources available to health. Much emphasis has been placed on environmental factors influencing the health of populations. Oil spillage affects both living and non-living components of the environment which in turn affect man directly and indirectly. This paper discusses the health implications of oil spillage, including the gastro-intestinal dermatologic and neurological effects associated with it. It advocates for better environmentally-friendly and sustainable techniques, particularly in resource-limited communities, where the socioeconomic, physical and invariably the health consequences will be least mitigated and most severe. Effective response and mitigation are necessary to cushion the adverse effects of inadvertent spills on the populations around effected regions.
\end{abstract}

Key words: Oil spillage, health, environment, non-communicable disease, pollution.

\section{INTRODUCTION}

The World Health Organization (WHO) defines health as a state of complete physical, mental and social well being and not the mere absence of disease or infirmity (WHO, 1948). This definition gives a holistic dimension to the issues concerning the health of individuals as well as whole communities (Jekel et al., 2007). It provides a template for defining various dimensions to health and its determinants, in spite of the criticisms put forward against this definition.

The environment has been recognized as an important contributor to the attainment of good health or ill health. The environment includes both living and non-living components. The quality of the environment affects man, influencing his actions while man's actions and inactions influence his environment (Roche, 2003). The increased burden of disease exerted by chronic non-communicable diseases has made it necessary for all factors influencing

\footnotetext{
*Corresponding author. E-mail: folasholeye@yahoo.com.
}

health to be studied. A lot of work has been done in the area of genetics, nutrition, lifestyle modification and environmental factors. Insightful epidemiological studies have linked specific health conditions with exposures to hazardous substances in the environment. Thus, environmental health deals with the impact the environment has on a population (WHO, 1993). A growing concern in the field of environmental health is the impact of oil spillage on the well being of individuals, residing close to the affected areas, as well as the degradation of the environment resulting from such spills.

Oil spills have been reported over several decades in many parts of the world, from Africa to North America. The Niger Delta region of Nigeria has been greatly affected by oil spillage in recent years, with its devastating effects on the environment and the populace. The federal government set up agencies to supervise the efforts of various stakeholders in combating the problems arising from oil spillage. While success has been recorded in a few quarters, a lot still needs to be done, in order to achieve a healthy environment. 
This paper discusses the implications of oil spillage on the well being of the public and their environment.

\section{THE OCCURRENCE OF OIL SPILLS}

A lot of oil is used and needs to be transported all over the world. Many countries depend on crude oil to power their economics. It has been estimated that the world uses about 2.73 billion gallons per day. States go to any length to acquire oil production capacity or to be assured access to free flow of oil. This has resulted in some form of conflict or the other in certain areas which may only possibly contain oil reserves. Oil production and trade fuel the economics of the world, making countries rely on the oil market supply chain. Some countries, like the United States, use up to 70 million gallons of oil daily. Crude oil is used as fuel for transportation and in factories; it is useful for electric power generation, asphalt production, wax, plastics, pesticide, fertilizers, heating, paints production and varnishes.

When oil spills, it is as a result of various contributing factors. It is estimated that 31.5 billion gallons of oil are at sea being transported, making it easy for spillage to occur. But not all spills come from tankers; some are from pipelines, oil wells, storage tanks and vessels cleaning out tanks. When oil of any type is released into the natural environment, the result is termed an "Oil Spill". Most people think of marine oil spills when spillage is mentioned, forgetting that the escape of oil into the natural environment is a problem on land as well.

The causes of oil spills can be broadly classified as follows:

1) Accident: This could be due to negligence or otherwise. This is the most widely acknowledge causes of spillage, involving very large cargo ships on sea;

2) Natural disasters includes earthquakes, adverse weather conditions, hurricanes, etc., it is also responsible for dumping of oil and gas in very large amount, into seas and oceans.

3) Intentional spills: This could be as a result of vandalism, terrorism, wars and washing of tanks and vessels into the sea.

A number of processes take place when oil spills. Oil generally floats because it is lighter than water. It needs to adhere to heavier particles like sand, algae and silt in order for it to sink. The following processes take place when spillage occurs:

1) Spreading, evaporation, emulsification

2) Petro/photo-chemical oxidation, and bacterial degradation.

Spreading takes place immediately oil is released on water. Oil usually floats and spreads out into a very thin film on the water surface known as "sheen". Sheens are often seen as silvery or rainbow-colored in puddles in parking lots. This process stands to be the most significant. Spreading is affected by gravitational forces which reduce film thickness and surface tension as well as inertia forces.

Bacterial degradation also occurs following spillage. Petroleum as well as its refined products, is a mixture of a wide range of hydrocarbon fractions with sulphur, oxygen, and nitrogen compounds. These fractions which include straight or short-branched alkanes, cyclo-alkanes, aromatic hydrocarbons, and heterocyclic compounds, form a potential carbon and energy source for microbial activities and hence are biodegradable. When spillage occurs in land, micro organisms make use of it in the soil, as energy source, with such additional nutrients as nitrogen, phosphorous, potassium and an adequate supply of oxygen. This microbial activity causes the disappearance of crude oil from the soil, after a considerable time.

Accumulation of carbon dioxide, water, ammonia and some other intermediates are unavoidable and the formation of waxy solids, by unknown biosynthetic processes are all hazardous and significantly long testing (Cole, 1997).

\section{OIL SPILLAGE AND THE ENVIRONMENT}

The environmental cost of oil spills has been extensive. They include the destruction of wildlife and biodiversity loss of fertile soil, pollution of air and drinking water, degradation of farmland and damage to aquatic ecosystems, all of which have caused serious health problems for the inhabitants of areas surrounding oil production and spill.

Oil can have a significant impact on marine larvae, birds and mammals in particular, and to a lesser extent on fish. Some components of oil are toxic if exposure occurs within the first two days of a spill. Oil on feathers hinders the water-repellency of birds. Oil on fur reduces its insulating capacity.

Several studies have been conducted on the effects of crude oil and its products on the environment. The acute and chronic consequences of oil spills deplete environmental resources which may result in death of living organisms in the environment, either immediately or with time (Hofer, 1998; Cole, 1997; MacFarland, 1998). The consequences oil spillage in the oceans is dreadful. The world's coastlines become polluted, fisheries and marine life get contaminated, colonies of sea birds are annihilated and other affected animals, leading to dead. The effects of oil on marine life are caused by either the physical nature of the oil (physical contamination and smothering) or its chemical components (toxic effects and accumulating) (Cole, 1997).

The environmental damage that results from oil retraction and production can also directly affect human 
life in the region. Damage can include pollution of water resources and contamination of the soil. Environmental devastation is damaging to vegetation, livestock, and invariably to the health of the humans. Oil spills can interfere with desalination plants which require a continuous supply of clean seawater (Awobajo, 1979). The impact of oil spills on living components of the environment may be lethal, sometimes affecting reproductive ability, physiologic processes and behavior of the organisms. These could be attributed to a number of factors, which are:

i) Type of the oil spilled, amount of the oil spilled, topography of the affected area, weather condition at the time of the spills, previous exposure of the area to oil, exposure to other pollutants, geomorphology of the coast, ii) State of the oil (whether fresh or not).

Coastline erosion is another problem associated with the environmental degradation due to oil spillage (lbe, 1998). This in turn poses a lot of problems for humans residing close to the affected areas.

\section{HEALTH IMPLICATIONS}

The emphasis of environment health has been the promotion, protection and sustenance of the health of people, as it relates to environmental conditions. It is not new that many epidemiological studies have been conducted to ascertain the effects of certain exposures on the health and well being of the concerned populations (Moeller, 1997). Hydrocarbon compounds contain substances that are hazardous to human health, causing a wide range of symptoms in various systems of the human body (Hofer, 1998). Oil spills are therefore harmful to human health in a multiplicity of ways, as extensively documented in scientific literature (Aquilera et al., 2010; Ha et al., 2008; Levy et al., 2011).

\section{Oil smoke}

Oil smoke from evaporation or burning is inhaled as volatile organic compounds. Oil vapors have been noted to cause headaches, dizziness, nausea, vomiting, eye and throat irritations, as well as breathing difficulties. People who inhale large amounts of fumes are in danger of chemical poisoning called hydrocarbon pneumonia.

Hofer (1998) discussed the environmental and health effects of crude oil contamination of the sea, during transportation. Oil contains a lot of particulate matter, polycyclic aromatic hydrocarbons, hydrogen sulphide, acidic aerosols, and volatile organic compounds which are detrimental to human health. These particles have been noted to be harmful to the heart and lungs. Volatile organic compounds can lead to respiratory problems, allergic reactions and weakened immune systems. They are also associated with harmful effects on the gastrointestinal tract and liver.

The Colorado Air Quality Control Commission (2006) report stated that oil and gas developments were the primary sources of the Denver region's air pollution. In the Rocky mountain region, the emission of sulphur (iv)oxide has increased by $147 \%$, as a by-product of petroleum production. The chemical aggravates heart and lung diseases and is poisonous at high levels.

Meo et al. (2009) conducted a study involving subjects that took part in the oil cleanup operators following spillage from a Creek tanker 'Tasman Spirit". They studied 50 exposed subjects matched with an equal number of controls, all non-smoking. They found that subjects involved in the cleanup exercise had higher health complaints as compared to their matched control. This led to the assertion that even occupational exposure to oilcontaminated water could lead to respiratory and general health complaints in workers.

A retrospective cohort study examined the acute health effects of the sea express oil spills; Lyons et al. (1999) concluded that residence in oil-contaminated area (as a result of spillage) are significantly associated with greater anxiety and depression scores, worse mental health, selfreported headache, sore eyes and sore throat after adjusting for age, sex, smoking status, anxiety and the belief that oil had affected their health. People from the exposed areas reported higher rates of physical and psychological symptoms than the control areas. The authors said the symptoms were those expected from the known toxicological effect of oil, suggesting a direct health effect on the exposed population (Lyons et al., 1999).

A similar study, which considered the psychological dimensions of the health sequelae of a community exposure in Texas, showed that adverse effects on the mental health of the people were recorded, as a result of exposure to hazardous chemical (Dayal et al., 1994).

Neurological effects have also been reported in several studies. Akpofure et al. (2000) in a study on integrated grass root post-impact assessment of acute damaging effects of continuous oil spills in the Niger Delta (January 1998 to January 2000) found increased phobic and anxiety disorders among the exposed. Some subjects were observed to have been perplexingly neurotic and schizophrenic. Agoraphobic disorder and tendencies were also noted. However, not all studies support an increased incidence of mental health problems following an oil spill, among people exposed to the pollutant.

A cross-section study examining the health-related quality of life and mental health in the medium-term aftermath of the "prestige oil spill" in Spain, found out significant increase in mental health problems due to oil spills. It concluded that almost 18 months after the 2002 sinking of the oil tanker, off the Calician coast, worse health-related quality of life (HRQOL) and mental health levels were not in evidence among subjects exposed to 
the spill. Nevertheless, some scales suggest the possibility of the slight impact on the mental health of residence in unaffected areas (Carrasco et al., 2007).

Gastro-intestinal symptoms, allergic reaction and generalized discomfort have also been reported as consequences of oil spillage. A retrospective cohorts study in England, after water contaminated incident near Worcester in April 1994, reported diarrhea, nausea, headache, abdominal pains, skin irritations and itchy eyes at higher rates among the exposed subjects when compared with the unexposed (Fowle et al., 1996).

A similar study following oil pollution on a beach near Karachi, Pakistan, measured enzymes and certain parameters in blood samples taken from study participants living or working in the vicinity of the polluted area. Lymphocytes and eosinophils were slightly raised, while some people had raised serum glutamic pyruvic transaminase levels (Khursid et al., 2008).

An important cause for concern is the cumulative effect of the crude oil contents on human health over a long period of time (Khursid et al., 2008). A study on the natural radioactivity and trace elements in crude oils implications for health, noted that Niger Delta oil has low metallic contents but the cumulative effects of the radioactivity and metallic properties on human health is of concern (Ajayi et al., 2009). An incident that also readily comes to mind, showing the effect of environmental pollution on human health is the Minamata Bay incident in Japan, where more than 100 cases of central nervous system damage fish, as a result of toxic waste disposal on the bay by an industrial outside. The compound in questions was methyl mercury (Kurtand et al., 1960; Jekel et al., 2007).

In essence, the health risks associated with oil spillage are real and require urgent attention. Preventive efforts are better coordinated with excellent results than palliative measures. Indeed, conditions like post-traumatic stress disorder, obsessive-compulsive disorder, somatoform stress disorder, hypochondrasis and affective stress disorders are better avoided than managed, by preventing spillage and if need be, immediately curtailing the spread of any accidental spills.

\section{SOCIAL DIMENSIONS OF OIL SPILLS}

Many communities in the Niger Delta region of Nigeria have been worst hit by the problem of oil spillage, with its attendant environmental, social and economic deprivation. The mangrove forests, intertidal shores and other natural habitats have been gravely affected by oil exploration and exploitation (Osuji et al., 2010; Omorodion, 2004; Amnesty International, 2009; Nwilo and Badejo, 2005). The people, who are mainly rural farmers, fishermen and traders, have lost their means of livelihood due to the menace, resulting in food shortages and unemployment, increasing their vulnerability to HIV/AIDS (Udonwa et al., 2004; Udoh et al., 2008).
Migrant workers in the oil industries, operating in the oil-rich regions have been found to engage in high-risk behaviours, over the years, though, many workplace programs are now addressing such and related issues (Nwauche and Akani, 2006; Macilwain, 2006). Weak public sector health delivery and educational systems, poverty, migration, concurrent sexual partnerships and food insecurity have been identified as the enabling factors for HIV transmission in the region (Udoh et al., 2009).

\section{MANAGEMENT OF OIL SPILLS}

The effective and full clean-up of spills, remains an intricate problem, all over the world. Technical methods have been characterized by various levels of success and challenges. The spill size and prevailing weather conditions affect the choice of methods. Common cleanup techniques include:

1) Containment and recovery, which involves the use of booms and skimmers for oil recovery, use of sorbents, dispersants, burning.

2) Bioremediation.

3) Shoreline clean-up.

4) Masterly inactivity, particularly, in open ocean spills where clean up is difficult and not efficient (Atlas, 1995; Hoff, 1993).

\section{INTERNATIONAL HEALTH REGULATIONS}

The 58th World Health Assembly IHR (WHA 55.16) is on global health response to natural occurrence, accidental release/deliberate use of biological and chemical agents/radio nuclear material that affect health.

Article 12 of IHR states "public health emergency of international member states can be determined by the process of deciding a public health emergency affecting members states by the Director-General (DG) of WHO". The roles of the DG and the affected state parties are clearly outlined. Oil spillage could also constitute a public health emergency when it occurs in a large great dimension, the guidelines stipulates by WHO must be followed.

\section{THE NIGERIAN EXPERIENCE}

Several laws and policies have been formulated to aid in management of oil spills in the country. Some other laws guide operations in the petroleum industry. As is characteristic of many other aspects of the country's public activities, the problem is not with the laws and policies, but with implementation. Some of these laws include:

1) Oil Pollution Act (OPA) of 1990.

2) Federal Environmental Protection Agency Act Cap 131 
LFN, 1990.

3) Endangered Species Decree Cap 108 LFN, 1990.

4) Harmful Waste Act Cap 165 LFN, 1990.

5) Petroleum (drilling and production) Regulations, 1969.

6) Mineral Oil (Safety) Regulations, 1963.

7) International Convention on the Establishment of an International Fund for compensation for Oil Pollution Damaged, 1971.

8) Convention on the Prevention of Marine Pollution damage, 1972.

9) African Convention on the Conservation of Nature and Natural Resources, 1968.

The Federal Government in 1962 promulgated the Environmental Impact Assessment (EIA) decree No. 86 of 1992, to protect and sustain the ecosystem. The law makes EIA compulsory for any major project that may have adverse effects on the environment (Olagoke, 1996; Ntukekpo, 1996). A number of federal and state agencies deal with the problem of oil spillage in Nigeria, including the Department of Petroleum Rouses (DPR), the Federal Ministry of Environment, the State Ministries of Environment and the National Maritime Authority.

A major issue that has remained a challenge is effective implementation of all documented guidelines, as well as coordination of all efforts of various stakeholders including civil society groups.

\section{GEOGRAPHIC INFORMATION (GIS) SYSTEM FOR OIL SPILLS MANAGEMENT}

A successful combating operation for a marine oil spill is dependent on a rapid response from the time of spill is reported until it is fully controlled (Wardley-Smith, 1977). In order to improve on the timely response and decisionmaking process, GIS is applied as an essential operational tool. Information on the exact position and size of the spill can be plotted on maps in a GIS environ-ment. It offers opportunities for integration of oil drift forecast models in the computer program framework (Milaka, 1995). Required information for oil spill sensitivity mapping can be depicted on a set of thematic maps using GIS even though they can in theory be depicted on a single sheet. GIS could also be used to assess the adequacy of any given oil spill contingency plan (Parthiphan, 1994; Smith and Loza, 1994).

\section{PREVENTIVE STRATEGIES}

It is a known fact that clean-up exercises, following oil spills, are not totally effective and neither do they fully restore the initial properties of the affected areas. Preventive plans are therefore more appropriate for health promotion and protection. Strategies to be employed include:

1) Improved piloting: training of ship and tanker crews.
2) Training of storage and pipeline facility crews.

3) Enforcing pollution rules at sea.

4) Building spill-resistant vessels.

5) Maintaining pipeline and vessels.

6) Preparing for spills response via effective training and (practice) drills.

Awareness creation is also an important strategy for the prevention of oil spills and associated health effects. The more enlightened people are, the easier it is for them to prevent, recognize and promptly report any case of oil spillage in their vicinity. In Nigeria, much of the incidents of oil spillage have also been attributed to sabotage. Political upspring and youth restiveness have greatly contributed to the destruction of oil pipelines. These could have been avoided if only the youth were educated about the adverse effect of spills on the environment and human health.

The various agencies, ministries and department, at local, national and international levels, need to be more pro-active in carrying out their stipulated duties as well as think of innovative ways to ensure the protection of the ecosystem and the health of the public.

Environmental health as a discipline needs to be taught in more details, with appropriate emphasis on contemporary practical issues facing the world today, including climate change and pollution (IoM, 1995). The problem of oil spills must be of high priority, so that more focused research may be conducted in this area.

\section{CONCLUSION}

Oil spillage is a major challenge in today's world. Everyone is affected in one way or the other. The resources of the environment are depleted and the ecosystem disrupted. So much can still be done in preventing further spills, as well as in the management of existing cases.

The Government health institutions, agencies and the general public all have a role to play. Policy implementation with effective monitoring and evaluation is needed. The time to act is now.

\section{REFERENCES}

Ajayi TR, Torto N, Tchokossa P, Akinlua A (2009). Natural Radioactivity and Trace Elements in Crude Oils: Implication for health. Environ. Geochem. Health 31(1):61-69.

Akpofure EA, Efere ML, Ayawa P (2000). The Adverse Effects of Crude Oil Spills in the Niger Delta, Nigeria. Urhobo Historical Society. Available (http://www.waado.org/environment/petrolpolution/oilspills/OilSpills_A dverseEffects.html)

Amnesty International (2009). Nigeria: Petroleum, pollution and poverty in the Niger Delta. London, United Kingdom Amnesty International Publications $\mathrm{p} 10$.

Atlas RM (1995). Petroleum Biodegradation and Oil Spill Bioremediation. Marine Pollut. Bull. 31:178-182.

Awobajo (1979). "Environmental Aspect of the Petroleum Industry in the 
Niger Delta: Problems and Solutions" in Proceedings of Petroleum Industry and the Environment of the Niger Delta $\mathrm{p} 145$

Carrasco JM, Perez-Gomez B, Lope V (2007). Health-related quality of life and mental health in the medium-term aftermath of the prestige oil spills in Galiza (Spain): A cross-sectional study. BMC Public Health 17:7:245.

Cole HA (1997). Pollution of the Sea and its Effects. Proc. R. Soc. Lond. B. Biol. Sci. 205(1158):17-30.

Dayal HH, Baranowski T, Li YH, Morris R (1994). Hazardous Chemicals; Psychological Dimension of the health Sequelae of a Community Exposure in Texas. J. Epidemoil. Community Health 8(6):560-568.

Fowle SE, Constantine CE, Fone D, McCloskey B (1996). An epidemiological study after a water contamination incident near Worcester, England in April 1994. J. Epidemiol. Community Health $50(1): 18-23$

Hofer J (1998). Environmental and Health effects resulting from marine bulk liquid transport. Environ. Sci. Pollut. Res. Int. 5(4):231-7.

Hoff R (1993). Bioremediation: An Overview of its development and use for Oil Spill cleanup. Marine Pollut. Bull. 26:476-481.

Ibe AC (1998) .Coastline Erosion in Nigeria. Ibadan University Press, Ibadan $\mathrm{p} 217$.

Institute of Medicine (1995). Environmental Health: Integrating a Missing Element into Medical Education. National Academy Press Washington, DC. pp. 44-51.

Jekel JF, Katz DL, Elmore JG, Wild DM (2007). Introduction to Preventive Medicine in: Epidemiology, Biostatistics and Preventive Medicine. 3rd Edition. WB Saunders, Philadelphia. p 225.

Khursid R, Sheikk MA, Igbal S (2008). Health of People Working/Living in the Viccinity of an Oil-polluted beach, near Karachi, Pakistan. East Mediterr. Health J. 14(1):179-82.

Kurtand LT (1960). Minamata Disease. World Neurol. 1:370-395.

Lyons RA, Temple JM, Evans D (1999). Acute Health Effects of the Sea Empress Oil Spills. J. Epidemiol. Community Health 53(5):306-10.

MacFarland HN (1998). Toxicology of Petroleum Hydrocarbons. Occup. Med. 3(3):445-454.

Macilwain C (2006). Oil firms back AIDS project in the Niger Delta. Nature 7:444(7120):663.

Meo SA, AL-Dress AM, Rasheed S, Meo IM (2009). Health complaints among subjects involved in Oil Clean up Operations during Oil Spillage from a Greek tanker "Tasmin Spirit". Int. J. Occup. Med. Environ. Health 22(2):143-148.

Milaka K (1995). Use of GIS as a tool for Operational Decision Making, Implementation of a National maritime Oil Spills Contingency Plan for Estonia, Carl Bro International a/s. Glostrup, Denmark.
Moeller DW (1997). Environmental Health. Revised Edition. Cambridge Mass Harvard University Press.

Ntukekpo R (1996). Spillage: Bane of Petroleum. Ultimate Water Technology and Environment. Environ. Res. J. 6(2):100-105

Nwauche CA, Akani Cl (2006). An assessment of high-risk sexual behavior and HIV transmission among migrant oil workers in the Niger Delta area of Nigeria. Niger. J. Clin. Pract. 9(1):48-51.

Nwilo PC, Badejo OT (2005). Oil spill problems and management in the Niger Delta. International Oil Spill Conference. Miami, Florida, USA. Euro. J. Sci. Res. 52(4):592-603

Olagoke W (1996). Niger Delta Environmental Survey: which way forward? Ultimate Water Technology and Environment. Environ. Res. J. 6(2):100-105

Omorodion FI (2004). The impact of petroleum refinery on the economic livelihoods of women in the Niger Delta region of Nigeria. JENDA. J. Cult. Afr. Women Studies 6:1-15

Osuji LC, Erondu ES, Ogali RE (2010). Upstream petroleum degradation of mangroves and intertidal shores: the Niger Delta experience. Chem. Biodivers. 7(1):116-128.

Parthiphan K (1994). Oil Spill Sensitivity mapping using a Geographical Information System. University of Aberdeen. EGIS Foundation.

Roche N (2003). Environmental Health in: Luaccs AO, Gilles HM (Eds). Short Textbook of Public Health Medicine for the Tropics. 4th Edition. London Book Power pp. 337-351.

Smith LA, Loza L (1994). Texas Turns to GIS for Oil Spill Management. Geo. Info. Syst. p 48.

Udoh IA, Mantell JE, Sandfort T, Eighmy MA (2009). Potential pathways to HIV/AIDS transmission in the Niger Delta of Nigeria: Poverty, migration and commercial sex. AIDS Care 21(5):567-574.

Udoh IA, Stammen RM, Mantell JE (2008). Corruption and oil exploration, expert agreement about the prevention of HIV/AIDS in the Niger Delta of Nigeria. Health Educ. Res. 23(4):670-681.

Udonwa NE, Ekpo M, Ekanem IA, Inem VA, Etokidem A (2004). Oil doom and AIDS boom in the Niger Delta Region of Nigeria. Rural Remote Health 4(2):273.

Wardley-Smith J (1977). The Control of Oil Pollution on the sea and Inland waters. Graham and Trotman Limited, London p 181.

World Health Organization (1948). Constitution of the World Health Organisation. Geneva: World Health Organization.

World Health Organization (1993). Consultative Meeting on Environmental Health Sofia, Bulgaria. October. 